\title{
Effect of nephrectomy on the rate and pattern of the disappearance of exogenous gastrin in dogs
}

\author{
B. GUY CLENDINNEN, ${ }^{1}$ DAVID D. REEDER, E. N. BRANDT, JR, AND \\ JAMES C. THOMPSON ${ }^{2}$ \\ From the Department of Surgery, The University of Texas Medical Branch, Galveston, Texas, USA
}

SUMMARY Studies of gastrin metabolism were performed in four dogs before and after nephrectomy. Synthetic human gastrin I was infused for two hours and serum samples were obtained at various times during and after infusion. Serum concentrations of gastrin were measured by radioimmunoassay. A two-compartment model was employed to calculate half-lives under each of four experimental conditions, low and high infusion rates, used both before and after nephrectomy. The model half-life was greatly prolonged after nephrectomy at both infusion rates (from $2.54 \mathrm{~min}$ to $5.15 \mathrm{~min}$ at the low rate, and from $2.85 \mathrm{~min}$ to $7.88 \mathrm{~min}$ at the high rate). The metabolic clearance rate, an expression of the rate of catabolism during infusion, decreased significantly after nephrectomy at both infusion rates. These observations indicate that the kidney is an important organ for the catabolism of exogenous gastrin.

Synthetic human gastrin I has been shown to have a short half-life when it is infused into dogs (Reeder, Jackson, Brandt, and Thompson, 1972b). This is in accordance with the brief physiological action that infusions of gastrin II have in man (Makhlouf, McManus, and Card, 1966).

Evidence has been presented that in dogs synthetic human gastrin may be inactivated in vivo by the kidney (Clendinnen, Davidson, Reeder, Jackson, and Thompson, 1969) and the liver (Thompson, Reeder, Davidson, Charters, Brückner, Lemmi, and Miller, 1969), and in vitro by the lung, skeletal muscle, and gastric fundus mucosa (Thompson, Reeder, Davidson, Jackson, and Clendinnen, in press). Of these sites the kidney is believed to be the most efficient (Clendinnen et al, 1969).

The effect of nephrectomy on the half-life of circulating exogenous gastrin in dogs has been determined by measuring the rate of disappearance

\footnotetext{
1 Present address: Department of Surgery, Bristol Royal Infirmary, Bristol, England. In receipt of Medical Research Council grant G.970/480/C.

${ }^{2}$ Requests for reprints should be sent to James C. Thompson,M.O., Department of Surgery, University of Texas Medical Branch, Galveston, Texas 77550, USA.

Supported by grants from the National Institutes of Health, AM15241, and by a grant from the John A. Hartford Foundation, Inc.

Received for publication 21 February 1973
}

of infused synthetic human gastrin I by the method of Reeder and associates (1972b).

\section{Method}

Synthetic human gastrin I was infused in four healthy, alert mongrel dogs weighing $17-22 \mathrm{~kg}$. A catheter for infusion was placed in the superior vena cava and a catheter for sampling was inserted in the iliac vein. Synthetic human gastrin I was given to the fasting dogs according to two dosage regimens. The low dose consisted of a loading injection of 4 micrograms $(\mu \mathrm{g})$, followed immediately by infusion at the rate of 400 nanograms $(\mathrm{ng}) / \mathrm{kg} /$ hour for two hours. The high dose was $8 \mu \mathrm{g}$ given as a load and $800 \mathrm{ng} / \mathrm{kg} /$ hour infused for two hours. These two infusions, given in random order, were separated by a rest period of two days. Infusion of gastrin at these rates resulted in nearly constant values for serum gastrin after one hour. Two basal serum samples for gastrin measurement were obtained before the administration of exogenous gastrin. Additional samples were obtained at the end of the infusion (time zero), and at one, two, three, four, five, eight, 10, 15, 30, and 60 minutes thereafter. One week after the completion of these experiments, both kidneys were removed under general anaesthesia. The dogs were then allowed to recover for two days 
and were again subjected to the same protocol of infusions of gastrin in random order as described above. The data subjected to analysis were all obtained in the first 15 minutes after stopping the infusion, since near basal concentrations of gastrin had been achieved by that time in the studies that were done before nephrectomy.

Gastrin concentrations were measured by radioimmunoassay in which a double-antibody technique was used (Charters, Odell, Davidson, and Thompson, 1969; Jackson, Reeder, and Thompson, 1972). The antigastrin antibody was developed in New Zealand white rabbits to synthetic human gastrin I (residues 2-17) conjugated to bovine serum albumin. All samples were assayed in duplicate; reproducibility was within $\pm 10 \%$. The average of the duplicates was used as the serum concentration for each of the measurements. The lower limit of sensitivity of the assays in this study was 40 picograms (pg) per millilitre of serum. If no gastrin was detected, the value of $40 \mathrm{pg} / \mathrm{ml}$ was recorded for purposes of calculation.

To permit analysis of the disappearance of the exogenous gastrin, the basal level, representing endogenous gastrin, was subtracted from each postinfusion concentration. All data used for analysis reflect the subtraction of basal gastrin levels.

The concentrations of gastrin in $\mathrm{pg} / \mathrm{ml}$ (observed minus basal) were plotted against time in each of the four experiments. The resulting curves on semilogarithmic paper were nonlinear. The results of Reeder and associates (1972b) indicated that a twocompartment model, as depicted in fig 1 , is appro-

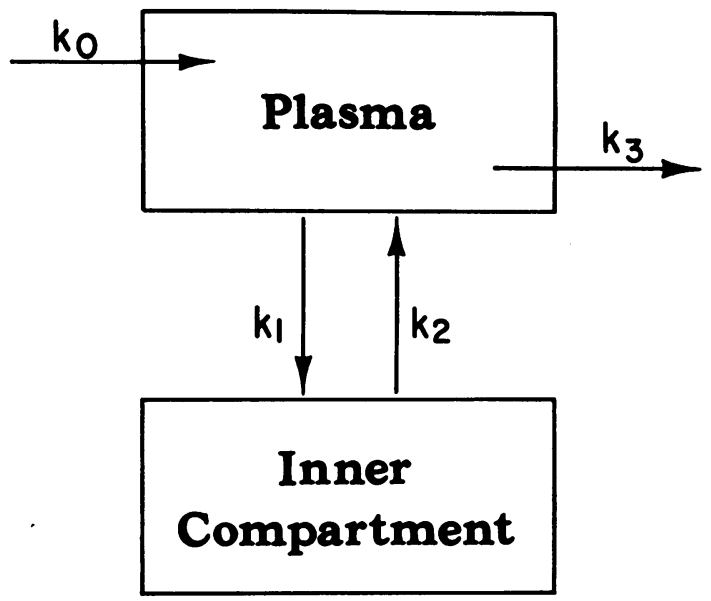

Fig 1 Two-compartment model for the disappearance of exogenous gastrin from the circulation. $k_{0}$ is the rate of infusion and $k_{3}$ the rate of irreversible loss from the plasma. $k_{1}$ and $k_{2}$ are the rates of transfer between the plasma and the inner compartment. priate for these data. Hence, each of the disappearance curves was resolved into two straight lines, one for the concentrations observed between eight and 15 minutes, and one for the concentrations observed during the early phase of the curve. As shown in fig 1 , the three rate constants to be estimated are: $\mathbf{k}_{1}=$ the rate of transfer from the plasma to the inner compartment; $\mathbf{k}_{\mathbf{2}}=$ the rate of transfer from the inner compartment to the plasma; and $\mathrm{k}_{3}=$ the rate of disappearance from the plasma. The rate of infusion is designated $k_{0}$. Therefore, a mathematical model consisting of the sum of two exponentials was adopted to describe the curve of disappearance.

The results were analysed initially by standard linear regression analysis (Steel and Torrie, 1960). The nonlinear program, NONLIN, developed by Metzler (1970) was used to obtain final estimates of $k_{1}, k_{2}$, and $k_{3}$, and from them revised estimates were calculated for the slopes of the first and second components of the disappearance curve, as described by Reeder and associates (1972b). These slopes are denoted by $\alpha$ and $\beta$ respectively.

Three half-lives were calculated by this technique for each curve: one for the first component of the computed curve, $T_{\frac{1}{2}}=\frac{0.693}{\alpha}$, one for the second component of the computed curve, $T_{\frac{1}{2}}=\frac{0.693}{\beta}$, and one for the total mathematical model, $T_{\frac{1}{2}}=\frac{0.693}{k_{3}}$ $(\log 2=0.693)$.

The metabolic clearance rate (MCR), defined as the volume of plasma cleared of hormone per unit time, was calculated by dividing the rate of infusion of the hormone per hour by the plasma concentration achieved at the end of the two-hour infusion. Results are expressed in millilitres of plasma per hour. Comparisons of mean MCRs were performed using the Student $t$ test for paired samples.

\section{Results}

Table $I$ is a summary of the gastrin values im-

\begin{tabular}{|c|c|c|c|c|}
\hline \multirow[t]{2}{*}{ Dog No. } & \multicolumn{2}{|c|}{ Low Dose $(400 \mathrm{ng} / \mathrm{kg} / \mathrm{hr})$} & \multicolumn{2}{|c|}{ High Dose $(800 \mathrm{ng} / \mathrm{kg} / \mathrm{hr})$} \\
\hline & $\begin{array}{l}\text { Before } \\
\text { Nephrectomy }\end{array}$ & $\begin{array}{l}\text { After } \\
\text { Nephrectomy }\end{array}$ & $\begin{array}{l}\text { Before } \\
\text { Nephrectomy }\end{array}$ & $\begin{array}{l}\text { After } \\
\text { Nephrectomy }\end{array}$ \\
\hline $\begin{array}{l}1 \\
2 \\
3 \\
4\end{array}$ & $\begin{array}{l}140 \\
260 \\
100 \\
480\end{array}$ & $\begin{array}{l}370 \\
406 \\
500 \\
560\end{array}$ & $\begin{array}{l}280 \\
380 \\
390 \\
250\end{array}$ & $\begin{array}{r}840 \\
800 \\
660 \\
2107\end{array}$ \\
\hline $\begin{array}{l}\text { Mean } \\
\text { SEM }\end{array}$ & $\begin{array}{r}245 \cdot 0 \\
85.4\end{array}$ & $\begin{array}{r}459 \cdot 0 \\
43 \cdot 4\end{array}$ & $\begin{array}{r}325 \cdot 0 \\
35 \cdot 2\end{array}$ & $\begin{array}{r}1101 \cdot 8 \\
227 \cdot 2\end{array}$ \\
\hline
\end{tabular}

Table I Serum gastrin concentrations $(\mathrm{pg} / \mathrm{ml})$ at end of two-hour infusion. 
mediately after each infusion (time zero) before and after nephrectomy. In each instance the value was higher after nephrectomy. The mean $( \pm$ SEM) basal gastrin value in these four dogs before was $44 \cdot 2 \pm$ $2 \cdot 1 \mathrm{pg} / \mathrm{ml}$ and after nephrectomy was $79.0 \pm 9 \cdot 7$ $\mathrm{pg} / \mathrm{ml}$. The mean gastrin value at the end of the low dose infusion was $245.0 \pm 85.4 \mathrm{pg} / \mathrm{ml}$ before and $459.0 \pm 43.4 \mathrm{pg} / \mathrm{ml}$ after nephrectomy. The mean gastrin after the high dose infusion was $325 \cdot 0 \pm 35 \cdot 2$ $\mathrm{pg} / \mathrm{ml}$ after nephrectomy. The mean gastrin after the high dose infusion was $325.0 \pm 35.2 \mathrm{pg} / \mathrm{ml}$ before and $1101 \cdot 8 \pm 227 \cdot 2 \mathrm{pg} / \mathrm{ml}$ after nephrectomy.

Figures 2 and 3 are semilogarithmic plots of the mean gastrin concentration at each time after the infusion. These figures illustrate that at both dose levels, the disappearance of gastrin was more rapid in the dogs before nephrectomy. At 15 minutes after

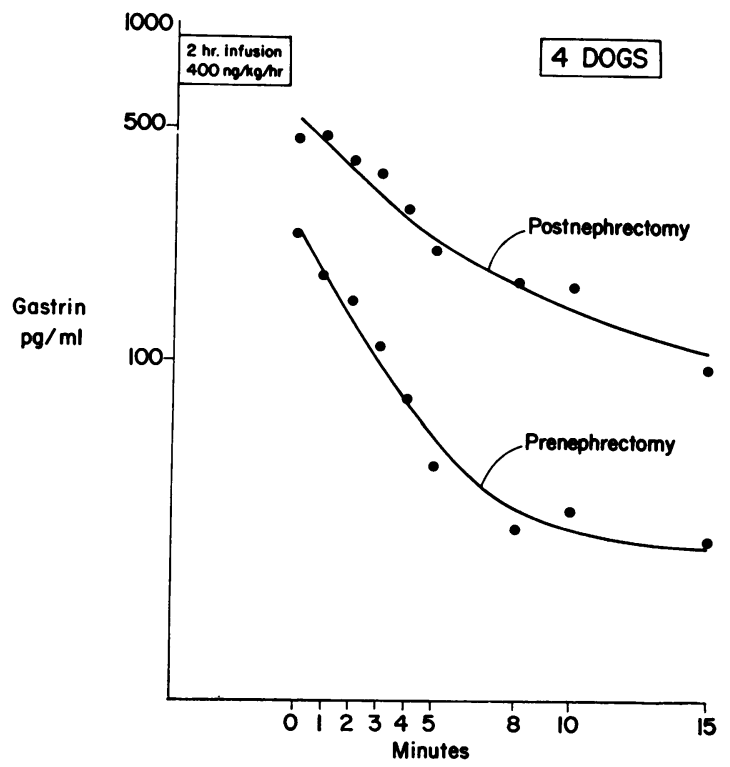

Fig 2 Semilogarithmic plot of the mean concentrations of gastrin at each time after infusion at the low dose. The curves have been empirically determined.

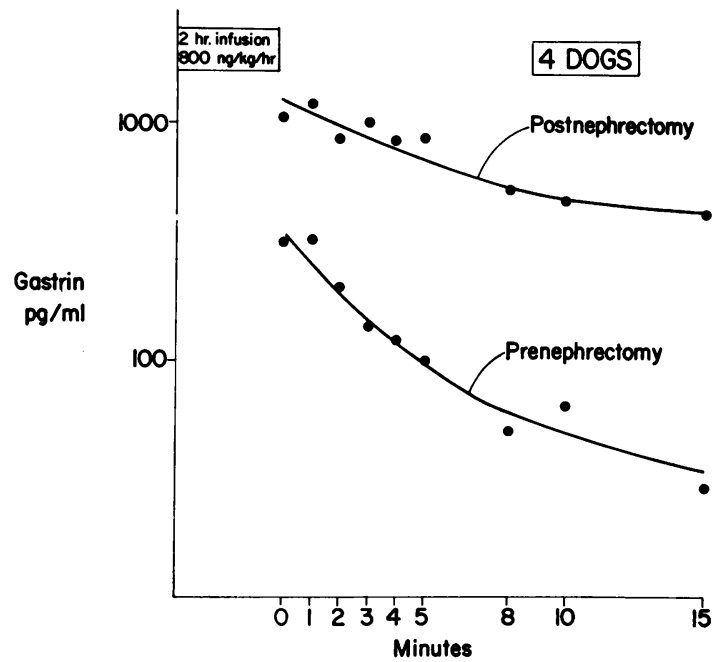

Fig 3 Semilogarithmic plot of the mean concentrations of gastrin at each time after infusion at the high dose. The curves have been empirically determined.

the low dose infusion (fig 2) the mean serum gastrin concentration had fallen from $245 \mathrm{pg} / \mathrm{ml}$ to $30 \mathrm{pg} / \mathrm{ml}$ in the experiments before nephrectomy, and from 459 to $98 \mathrm{pg} / \mathrm{ml}$ after nephrectomy. At 15 minutes after the high-dose gastrin infusion (fig 3), it had fallen from 325 to $35 \mathrm{pg} / \mathrm{ml}$ before nephrectomy and from 1101 to $429 \mathrm{pg} / \mathrm{ml}$ after nephrectomy.

Figures 4 and 5 illustrate the quality of fit of the model for a dog (no. 2) for studies both before and after nephrectomy at each of the two dose levels.

\begin{tabular}{llllll}
\hline Dog No. & \multicolumn{2}{l}{ Before Nephrectomy } & & \multicolumn{2}{l}{ After Nephrectomy } \\
\cline { 2 - 3 } \cline { 5 - 6 } \cline { 5 - 6 } & Low Dose & High Dose & & Low Dose & High Dose \\
\hline 1 & 23.95 & 52.59 & & 47.31 & 215.40 \\
2 & 26.55 & 23.33 & & 33.15 & 121.80 \\
3 & 1211 & 49.75 & & 76.59 & 121.00 \\
4 & 67.51 & 54.63 & & 98.84 & 230.33 \\
\hline
\end{tabular}

Table II Variations of data from calculated curves expressed as standard deviation

\begin{tabular}{|c|c|c|c|c|c|c|}
\hline \multirow[t]{3}{*}{ Dog No. } & \multicolumn{6}{|l|}{ Low Dose } \\
\hline & \multicolumn{3}{|c|}{ Before Nephrectomy } & \multicolumn{3}{|l|}{ After Nephrectomy } \\
\hline & Initial Component & Final Component & Model & Initial Component & Final Component & Model \\
\hline $\begin{array}{l}1 \\
2 \\
3 \\
4\end{array}$ & $\begin{array}{l}2.80 \\
1.55 \\
2.45 \\
1.91\end{array}$ & $\begin{array}{r}6.46 \\
16.66 \\
4 \cdot 75 \\
16.34\end{array}$ & $\begin{array}{l}3.73 \\
1.59 \\
2.75 \\
2.09\end{array}$ & $\begin{array}{l}8 \cdot 42 \\
2 \cdot 80 \\
2 \cdot 83 \\
1 \cdot 54\end{array}$ & $\begin{array}{r}693.00 \\
37 \cdot 35 \\
68.01 \\
5 \cdot 23\end{array}$ & $\begin{array}{l}8 \cdot 51 \\
3 \cdot 35 \\
3 \cdot 54 \\
5 \cdot 18\end{array}$ \\
\hline $\begin{array}{l}\text { Mean } \\
\text { SEM }\end{array}$ & $\begin{array}{l}2 \cdot 18 \\
0 \cdot 28\end{array}$ & $\begin{array}{r}11.05 \\
3.17\end{array}$ & $\begin{array}{l}2.54 \\
0.46\end{array}$ & $\begin{array}{l}3.90 \\
1.54\end{array}$ & $\begin{array}{l}200 \cdot 90 \\
164 \cdot 50\end{array}$ & $\begin{array}{l}5 \cdot 15 \\
1 \cdot 19\end{array}$ \\
\hline
\end{tabular}

Table III Gastrin half-lives (min) 


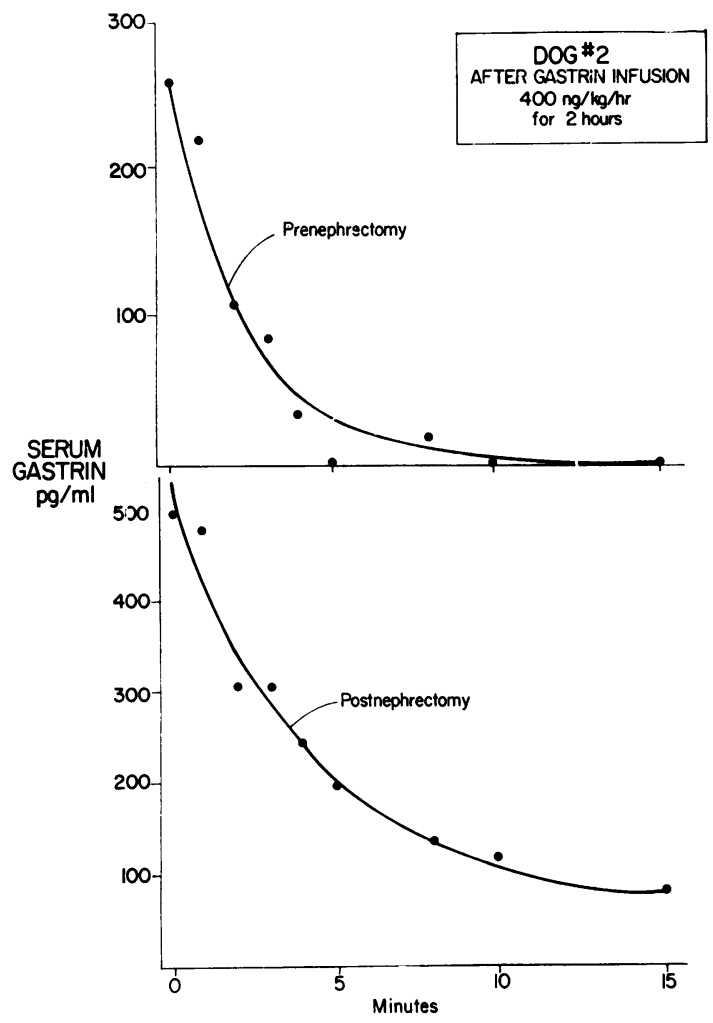

Fig 4 Computer-derived curves for a dog (no. 2) receiving the low infusion rate.

The prenephrectomy curves were a better fit than the postnephrectomy curves at both levels of infusion. The standard deviation which measures the variation of the observed data from the calculated curve for each dog is included in table II. In each instance the standard deviation was higher after nephrectomy.

Table III includes the three half-lives for each dog under each of the four experimental conditions, ie, low and high dose, before and after nephrectomy.

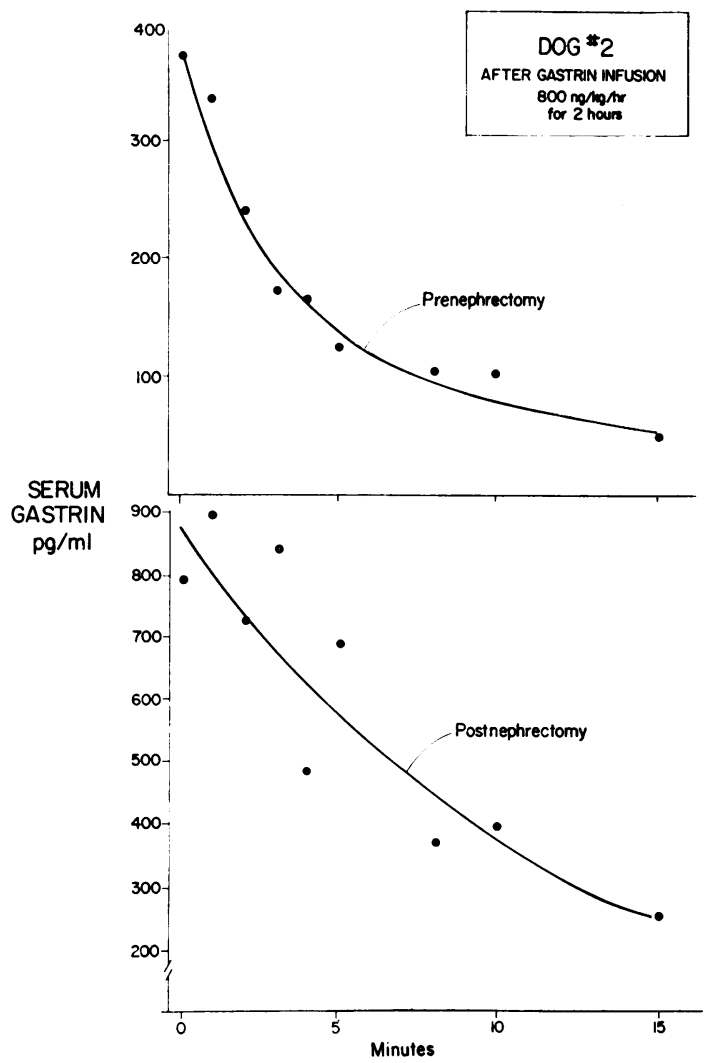

Fig 5 Computer-derived curves for a dog (no. 2) receiving the high infusion rate.

Means and standard errors are included. These data clearly indicate a prolongation of the half-lives after the kidneys were removed. For example, the mean model half-life of gastrin after the low dose infusion was increased from $2.54 \pm 0.46$ minutes before nephrectomy to $5 \cdot 15 \pm 1 \cdot 19$ after nephrectomy. The model half-life after the high dose infusion was increased from $2.85 \pm 0.52$ before nephrectomy to $7 \cdot 88 \pm 0.30$ minutes after nephrectomy.

\begin{tabular}{|c|c|c|c|c|c|c|}
\hline \multirow[t]{3}{*}{ Dog No. } & \multicolumn{6}{|l|}{ High Dose } \\
\hline & \multicolumn{3}{|l|}{ Before Nephrectomy } & \multicolumn{3}{|l|}{ After Nephrectomy } \\
\hline & Initial Component & Final Component & Model & Initial Component & Final Component & Model \\
\hline $\begin{array}{l}1 \\
2 \\
3 \\
4\end{array}$ & $\begin{array}{l}1.08 \\
1.87 \\
1 \cdot 28 \\
2.25\end{array}$ & $\begin{array}{r}3.05 \\
13.35 \\
4.29 \\
15.97\end{array}$ & $\begin{array}{l}3.01 \\
2.66 \\
1.61 \\
4 \cdot 12\end{array}$ & $\begin{array}{l}7 \cdot 80 \\
8 \cdot 52 \\
7 \cdot 89 \\
5 \cdot 16\end{array}$ & $\begin{array}{r}693.00 \\
729 \cdot 40 \\
845 \cdot 12 \\
>1000 \cdot 00\end{array}$ & $\begin{array}{l}7.90 \\
8.52 \\
8.01 \\
7.07\end{array}$ \\
\hline $\begin{array}{l}\text { Mean } \\
\text { SEM }\end{array}$ & $\begin{array}{l}1.62 \\
0.27\end{array}$ & $\begin{array}{l}9 \cdot 17 \\
3 \cdot 23\end{array}$ & $\begin{array}{l}2.85 \\
0.52\end{array}$ & $\begin{array}{l}7 \cdot 34 \\
0 \cdot 75\end{array}$ & $>816.79$ & $\begin{array}{l}7 \cdot 88 \\
0 \cdot 30\end{array}$ \\
\hline
\end{tabular}

Table III Gastrin half-lives (min) 
The metabolic clearance rates (expressed as millilitres of plasma cleared of gastrin per hour) calculated for each study in each of the four dogs, are given in table IV. Nephrectomy resulted in a consistent diminution in the MCR of gastrin after the infusion of either dosage of gastrin. This decrease was significant $(P<0.05)$ in both instances.

\begin{tabular}{|c|c|c|c|c|}
\hline \multirow[t]{2}{*}{ Dog No. } & \multicolumn{2}{|c|}{ Low Dose $(400 \mathrm{ng} / \mathrm{kg} / \mathrm{hr})$} & \multicolumn{2}{|c|}{ High Dose $(800 \mathrm{ng} / \mathrm{kg} / \mathrm{hr})$} \\
\hline & $\begin{array}{l}\text { Before } \\
\text { Nephrectomy }\end{array}$ & $\begin{array}{l}\text { After } \\
\text { Nephrectomy }\end{array}$ & $\begin{array}{l}\text { Before } \\
\text { Nephrectomy }\end{array}$ & $\begin{array}{l}\text { After } \\
\text { Nephrectomy }\end{array}$ \\
\hline $\begin{array}{l}1(22 \mathrm{~kg}) \\
2(21) \\
3(19) \\
4(17)\end{array}$ & $\begin{array}{l}39462 \\
37668 \\
34081 \\
30493\end{array}$ & $\begin{array}{ll}24 & 410 \cdot 5 \\
23 & 301 \cdot 0 \\
21 & 082 \cdot 0 \\
18 & 863 \cdot 0\end{array}$ & $\begin{array}{l}52853 \\
50450 \\
45646 \\
40841\end{array}$ & $\begin{array}{l}15817 \\
15098 \\
13660 \\
12222\end{array}$ \\
\hline $\begin{array}{l}\text { Mean } \\
\text { SEM }\end{array}$ & $\begin{array}{cc}35426.0 & \\
1988.7 & \\
& P<\end{array}$ & $\begin{array}{l}21914 \cdot 0 \\
1230 \cdot 1 \\
0.05\end{array}$ & $\begin{aligned} 47447.5 & \\
2663.4 & \\
& P<\end{aligned}$ & $\begin{array}{c}14199 \cdot 0 \\
797 \cdot 1 \\
0.05\end{array}$ \\
\hline
\end{tabular}

Table IV Metabolic clearance rate (ml plasma/hr)

\section{Discussion}

Three half-lives were calculated for each of the four experimental situations in this investigation. Of these the 'model' half-life is a measure of the disappearance rate due to all operative mechanisms. The other two half-lives represent two exponential functions which describe the observed disappearance curve. The initial phase probably represents mixing and distribution of gastrin from the vascular space (Silvers, Swenson, Farquhar, and Reaven, 1969), and the later component probably represents catabolism of the hormone. The analytical method which has been used is only suitable when mixing is rapid relative to metabolism (Stern, Farquhar, Silvers, and Reaven, 1968). Gastrin was infused to a steady state concentration in an attempt to obviate errors due to mixing. Saturation of the spaces of distribution, however, cannot be assured and the estimate of the first half-life probably reflects residual mixing and early catabolism. The second component of the disappearance curve represents the summation of catabolic mechanisms for the hormone (Stern et al, 1968).

The results of the first part of this study confirm the previous report (Reeder et al, 1972b) of the rate of disappearance of exogenous gastrin in intact dogs. In our four dogs the model half-life was found to be $2.54 \pm 0.46$ minutes for the low dose of exogenous gastrin and 2.85 \pm 0.52 for the high dose. Although these half-lives are greater than the 1.89 minutes reported by Reeder and colleagues (1972b), who used a dose similar to the present high dose schedule in $10 \mathrm{dogs}$, the figures are of a comparable order, and minor differences in the methods of the two studies may account partly for the difference between them. In addition, variations in the half-life among individual dogs are quite wide (table III). The results of both studies are in general agreement with those of previous investigators (Blair, Farra, Richardson, and Steinbok, 1970; Ganguli, Elder, Smith, and Hunter, 1970; Ganguli, Cullen, and Irvine, 1971; McGuigan, Isaza, and Landor, 1971; Newton and Jaffe, 1971; Yalow and Berson, 1970a) but are not directly comparable because of differences in methodology.

The kidney is known to be active in the degradation of several peptide hormones (Lauson, 1967; Narahara and Williams, 1957; Richards and Sayers, 1951; Salmon, Utiger, Parker, and Reichlin, 1962; Sonenberg and Money, 1955). Early unpublished studies in our laboratory with injections of radioiodinated gastrin showed the renal cortex to take up activity to a greater degree than many other organs that were measured. This finding has been confirmed by Newton and Jaffe (1971). Clendinnen and associates (1971) showed that the dog kidney inactivated $40 \%$ of exogenous synthetic human gastrin presented to it, and recent studies by Hjelmquist, Reeder, Brandt, and Thompson (1972) indicated that the kidney inactivates $30 \%$ of elevated levels of endogenous gastrin during a single transit through its circulation. It is possible then that the kidney is the major organ for catabolism of both exogenous and endogenous gastrin, although the gastric fundus (Evans, Reeder, and Thompson, in preparation) and small bowel (Temperley, Stagg, and Wylie, 1971; Becker, Reeder, and Thompson, submitted for publication) appear to have the capacity for gastrin catabolism when serum levels of gastrin are elevated. Reeder and associates (1972a) have recently shown that the liver has no apparent physiological role in gastrin catabolism.

This study demonstrates that nephrectomy increases the model half-life for the low dose from 2.54 minutes to 5.15 minutes and for the high dose from 2.85 minutes to $\mathbf{7 . 8 8}$ minutes (table III). The observation that the increase in half-life after nephrectomy is much greater at the high dose than at the low dose suggests that the limits of the durable mechanisms for the catabolism of gastrin are being approached at the higher infusion rate. The half-life of the initial component is prolonged from $2 \cdot 18$ to 3.90 minutes at the low dose and from 1.62 to 7.34 minutes at the high dose. The significance of this is not known but probably represents slowing of catabolic processes after nephrectomy.

The half-life of the second or 'catabolic' component of the disappearance curve in intact dogs is 11.05 minutes at the low dose and 9.17 at the high dose. Nephrectomy results in a profound increase in these half-lives in the individual dogs (with one 
exception at the low dose) and the change is much more pronounced with the high dosage. The variation among dogs is quite large. The probable significance of this prolongation is that once distribution and mixing are accounted for, the rate of actual breakdown of gastrin in the absence of the kidneys is greatly slowed and may be exceeded by the rate of infusion of gastrin used in these experiments. The 'model' half-life is changed little, however, owing to masking of impaired catabolism (apparently by the distributional and mixing phases).

Calculation of the metabolic clearance rates from the data of constant infusion studies is independent of the number of compartments necessary to describe the system (Tait and Burstein, 1964). We have calculated the MCR, therefore, as an estimate of rate of catabolism during the period of constant infusion. In these studies the metabolic clearance rate was significantly decreased following nephrectomy at both dose levels of infusion. This decrease following nephrectomy is additional evidence that the kidney is an important organ for catabolism of gastrin.

Metabolic studies with other polypeptide hormones, such as insulin (Field, Webster, and Drapanas, 1968), have shown that the rate of destruction may rise with increases in the concentrations in the blood. Consequently, measurements of the rate of metabolism of gastrin at different levels might be expected to yield different results. The half-lives for gastrin in intact dogs determined in this study at two dosages of exogenous gastrin, however, were in close agreement.

Gastrin used in these studies was the small or heptadecapeptide form of human gastrin prepared synthetically. Most of the circulating gastrin has been found to be in a larger form (Yalow and Berson, $1970 \mathrm{~b}$ ) in which the heptadecapeptide is bound covalently to a peptide which may protect it from inactivation. The rapid rates of disappearance we have measured may be valid only at high levels of exogenous gastrin. They may also be influenced by the species configuration (human) of the exogenous gastrin used in these experiments in dogs.

\section{References}

Becker, H. D., Reeder, D. D., and Thompson, J. C. Gastrin inactivation by the small bowel. Gastroenterology, in press.

Blair, E. L., Farra, Y., Richardson, D. D., and Steinbok, P. (1970). The half-life of exogenous gastrin in the circulation. J. Physiol. (Lond.), 208, 299-315.

Charters, A. C., Odell, W. D., Davidson, W. D., and Thompson, J. C. (1969). Gastrin: immunochemical properties and measurement by radioimmunoassay. Surgery, 66, 104-110.

Clendinnen, B. G., Davidson, W. D., Reeder, D. D., Jackson, B. M., and Thompson, J. C. (1971). Renal uptake and excretion of gastrin in the dog. Surg. Gynec. Obstet., 132, 1039-1043.

Field, J. B., Webster, M., and Drapanas, T. (1968). Evaluation of factors regulating hepatic control of insulin homeostasis. J. clin. Invest., 47, 33a-34a.
Ganguli, P. C., Cullen, D. R., and Irvine, W. J. (1971). Radioimmunoassay of plasma-gastrin in pernicious anaemia, achlorhydria without pernicious anaemia, hypochlorhydria, and in controls. Lancet, 1, 155-158.

Ganguli, P. C., Elder, J. B., Smith, I. S., and Hunter, W. M. (1970).

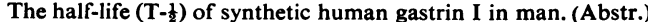
Brit. J. Surg., 57, 848.

Hjelmquist, U. B. E., Reeder, D. D., Brandt, E. N., Jr., and Thompson J. C. (1972). Effect of the kidney on endogenous gastrin. Surg. Forum, 23, 318-320.

Jackson, B. M., Reeder, D. D., and Thompson, J. C. (1972). Dynamic characteristics of gastrin release. Amer. J. Surg., 123, 137-142.

Lauson, H. D. (1967). Metabolism of anti-diuretic hormones. Amer. J. Med., 42, 713-744.

McGuigan, J. E., Isaza, J., and Landor, J. H. (1971). Relationships of gastrin dose, serum gastrin, and acid secretion. Gastroenterology, 61, 659-666.

Makhlouf, G. M., McManus, J. P. A., and Card, W. I. (1966). Action of gastrin II on gastric secretion in man. In Gastrin (UCLA Forum Med. Sci., no. 5), edited by M. I. Grossman, pp. 139169. University of California Press, Berkeley, California. Butterworths, London.

Metzler, C. M. (1970). NONLIN: a computer program for parameter estimation in non-linear situations. Upjohn, Kalamazoo, Michigan.

Narahara, H. T., and Williams, R. H. (1957). Degradation of glucagon$I^{131}$ by rat tissues in vitro. Endocrinology, 60, 285-289.

Newton, W. T., and Jaffe, B. M. (1971). The fate of intravenously administered radiolabeled gastrin. Surgery, 69, 34-40.

Reeder, D. D., Brandt, E. N., Jr., Watson, L. C., Hjelmquist, U. B. E., and Thompson, J. C. (1972a). Pre- and posthepatic measurements of mass of endogenous gastrin. Surgery, 72, 34-41.

Reeder, D. D., Jackson, B. M., Brandt, E. N., Jr., and Thompson, J. C. (1972b). Rate and pattern of disappearance of exogenous gastrin in dogs. Amer. J. Physiol., 222, 1571-1574.

Richards, J. B., and Sayers, G. (1951). Fate and excretion of adrenocorticotrophic hormone. Proc. Soc. exp. Biol. (N.Y.), 77, 87-93.

Salmon, S., Utiger, R., Parker, M., and Reichlin, S. (1962). The fate of $\mathrm{I}^{131}$ labeled human growth hormone in the rabbit. Endocrinology, 70, 459-464.

Sandberg, A. A., and Slaunwhite, W. R., Jr. (1963). Transcortin: a corticosteroid-binding protein of plasma. V. In vitro inhibition of cortisol metabolism. J. clin. Invest., 42, 51-54.

Silvers, A., Swenson, R. S., Farquhar, J. W., and Reaven, G. M. (1969). Derivation of a three compartment model describing disappearance of plasma insulin-181 $I$ in man. $J$. clin. Invest. 48, 1461-1469.

Sonenberg, M., and Money, W. L. (1955). The fate and metabolism of anterior pituitary hormones. Rec. Prog. hormone Res., 11, 43-82.

Steel, R. G. D., and Torrie, J. H. (1960). Principles and Procedures of Statistics, 161-182. McGraw-Hill, New York.

Stern, M. P., Farquhar, J. W., Silvers, A., and Reaven, G. M. (1968). Insulin delivery rate into plasma in normal and diabetic subjects. J. clin. Invest., 47, 1947-1957.

Tait, J. F., and Burstein, F. (1964). In vivo studies of steroid dynamics in man. In The Hormones, edited by G. Pincus, K. V. Thimann, and E. B. Astwood, 5, 441-557. Academic Press, New York and London.

Temperley, J. M., Stagg, B. H., and Wyllie, J. H. (1971). Disappearance of gastrin and pentagastrin in the portal circulation. Gut, 12, 372-376.

Thompson, J. C., Reeder, D. D., Davidson, W. D., Charters, A. C.' Brückner, W. L., Lemmi, C. A. E., and Miller, J. H. (1969) Effect of hepatic transit of gastrin, pentagastrin, and histamine measured by gastric secretion and by assay of hepatic vein blood. Ann. Surg., 170, 493-505.

Thompson, J. C., Reeder, D. D., Davidson, W. D., Jackson, B. M., and Clendinnen, B. G. (1973). Studies on the metabolism of gastrin. In Frontiers in Gastrointestinal Hormone Research: Nobel Symposium XVI, edited by S. Andersson. Almquist and Wiksell, Uppsala. In press.

Yalow, R. S., and Berson, S. A. (1970a). Radioimmunoassay of gastrin. Gastroenterology, 58, 1-14.

Yalow, R. S., and Berson, S. A. (1970b). Size and charge distinctions between endogenous human plasma gastrin in peripheral blood and heptadecapeptide gastrins. Gastroenterology, 58, 609-615. 